\title{
WNT5B Gene
}

National Cancer Institute

\section{Source}

National Cancer Institute. WNT5B Gene. NCI Thesaurus. Code C127921.

This gene plays a role in the modulation of Wnt-frizzled signaling pathways. 